Food, Dairy and Home Economic Research

\title{
EFFECT OF ADDITION OF FULL FAT AND DEFATTED FLAXSEED FLOUR ON THE QUALITY OF PAN BREAD
}

\author{
Mahmoud A.E. Mansour", G.A. Galal and S.M. Abu El-Maaty \\ Food Sci. Dept., Fac. Agric., Zagazig Univ., Egypt
}

\section{Received: 05/11/2017 ; Accepted: 29/11/2017}

\begin{abstract}
Full flaxseed flour (FFF) and Defatted flaxseed flour (DFF) are rich sources of some valuable biochemical compounds such as phenolics, flavonoids and dietary fiber. Effect of FFF and DFF at different addition levels $(5,10$ and 15\%) on the flour characteristics, dough rheological properties, bread chemical composition, physical and sensory characteristics of pan bread were investigated. The results of Mixolab analysis showed that flour water absorption and dough stability were decreased as FFF or DFF addition levels increased. Fortification of wheat flour with FFF and/or DFF up to $15 \%$ increased the crude protein from 12.05 to $14.47 \%$, crude fiber from 0.37 to $1.38 \%$ and ash from 3.64 to $5.54 \%$ while, caloric values of the obtained bread were decreased. The results also showed that wheat flour could be fortified with FFF or DFF up to $10 \%$ for preparing high quality pan bread without any changes in its physical and sensory characteristics.
\end{abstract}

Key word: Full fat flaxseed, defatted flaxseed, fortification, pan bread, sensory evaluation.

\section{INTRODUCTION}

Flaxseed or linseed (Linum ustitatissimum L.) has been used in many foods and medicinal products for long times. It has been used in various forms such as flour, oil and seeds. Flaxseed and flaxseed oil are considered as healthy due to their contents of various bioactive compounds (El-Demery et al. 2015). It is cultivated in more than 50 countries; however, Canada is the main flax producer, followed by China, United States and India. Utilization of flaxseed in food and in food products has been increasing due to its high content of essential omega-3 fatty acid, alpha-linolenic acid, dietary fiber and natural phenolic antioxidants (Kasote, 2013).

Flaxseed is classified as a functional food because of its high fiber $(27.3 / 100 \mathrm{~g})$, protein $(18.3 / 100 \mathrm{~g})$, potassium $(813 \mathrm{mg} / 100 \mathrm{~g})$, linolenic acid $(22.8 / 100 \mathrm{~g})$ and lignan contents (6.1 to $13.3 \mathrm{mg} / \mathrm{g}$ ) (Johnson et al., 2000). It has a unique fatty acid profile. It is high in polyunsaturated fatty acids $(73 \%$ of the total

\footnotetext{
* Corresponding author: Tel. : +201098354354

E-mail address: mattef2018@gmail.com
}

fatty acids), moderate in monounsaturated fatty acids $(18 \%)$ and low in saturated fatty acids (9\%). Linoleic acid, and omega-6 fatty acid, constitutes about 16 .

Per cent of total fatty acids, whereas $\alpha$ linolenic acid (ALA) constitutes about 57\% the highest of any oil seeds (Thompson et al., 1995; Kaur et al., 2013). Furthermor, flaxseed contains substantial amounts of phenols (mainly p-coumaric, vanillic, sinapic and ferulic, which are present as glycosides with ester and ether bonds) and flavonoids such as flavone $\mathrm{C}$ - and flavone O-glycosides of flavones and tannins (Kajla et al., 2014; Seczyk et al., 2017).

Bread is one of the most widely consumed as human meal in the world. Bread making technologicaly is one of the oldest technology known (Selomulyo and Zhou, 2007). It is an important staple food in a majority of countries which basically made of hard and/or soft wheat flour, yeast, fat, sugar, salt and water (Badifu $\boldsymbol{e t}$ al., 2005). Bread is the cereal product that is naturally low in protein and nutritionally not a balance diet because it is low content of the 
essential amino acid lysine (Gimai et al., 2003; Agu et al., 2010). Bread nutritional value improvement using whole grains or other seeds has become popular due to its positive health effects. Recently, functional foods are gaining importance as they render benefits beyond their nutrition and energy values in promoting health and preventing certain chronic diseases, cancer, diabetes, autoimmune disorders, arthritis, and arrhythmia (Shahidi, 2002). A growing interest was observed in the use of flaxseed as functional ingredients in food industry to improve the quality of various cereal-based products such as bread, pasta, muffins, bagels, cookies and cakes (Kajla et al., 2014; Mercier et al., 2014).

This study aimed to evaulate the effect of addition full flaxseed flour (FFF) and defatted flaxseed flour (DFF) on the nutritional, functional and sensory characteristics of pan bread.

\section{MATERIALS AND METHODS}

\section{Materials}

Flaxseed (Linum usitatissimum L.) was obtained from Agricultural Research Center, Giza, Egypt. Wheat flour ( $72 \%$ extraction) and other components were purchased from local market, Zagazig City, Sharkia Governorate, Egypt.

\section{Preparation of flaxseed flour}

The cleaning of flaxseed was performed manually to remove damaged seeds, dust particles, seeds of other grains/crops and other impurities such as metals and weeds. Then, seeds were powdered using a laboratory mill (Moulinex, france). The full fat flaxseed flour (FFF) was sieved through a 60 mesh screen until fine powder was obtained and kept at $4{ }^{\circ} \mathrm{C}$ in polyethylene pages until used.

\section{Preparation defatted flaxseed flour}

Defatted flaxseed flour was prepared according to the method used by Siddiq et al (2009). Briefly, an exactly weighed amount of flaxseed flour or ground flaxseed was placed in a conical flask, and $n$-hexan was added in the ratio of 10:1 (solvent: flour). The mixture was stirred for $16 \mathrm{hr}$., then filtered by filter paper. More $n$-hexan was added to wash fat traces, and the mixture was filtered using filter paper again.
The defatted flaxseed flour (DFF) was dried in open air at room temperature (about $26^{\circ} \mathrm{C}$ ). Full fat flaxseed (FFF) or DFF were stored in airtight plastic containers and were kept in a refrigerator until used.

\section{Wheat-flaxseed flour blends}

Wheat flour ( $72 \%$ extraction), with a moisture content of $13.26 \mathrm{~g} / 100 \mathrm{~g}$, was used for preparing wheat-flaxseed flour blends. FFF or DFF was added to wheat flour at levels 5, 10 and $15 \mathrm{~g} / 100 \mathrm{~g}$. Each treatment, containing both types of flours, was mixed thoroughly by sieving 3 times to achieve uniformity in distribution of flour particles. Wheat-flaxseed flour blends were stored at $4^{\circ} \mathrm{C}$ in polyethylene bags until used for bread making.

\section{Dough rheological properties}

Dough rheological was performed using Mixolab device (Chopin, tripettet Renaud, Paris, France) according to the method of AACC (2002a). Sample of 50 grams was placed into the Mixolab bowl and mixed. After tempering the solids, the water required for optimum consistency was added. Special attention was carried to the determination of the water absorption; in order to ensure the complete hydration of all the components (Bonet and Rosell, 2006). The running parameters of the Mixolab device during the tests are: mixing rate $80 \mathrm{rpm}$, temperature of the first plateau $30^{\circ} \mathrm{C}$, duration of the first plateau $8 \mathrm{~min}$., temperature of the second plateau $90^{\circ} \mathrm{C}$, first temperature gradient $4^{\circ} \mathrm{C} / \mathrm{min}$, duration of the second plateau $7 \mathrm{~min}$, second temperature gradient $4^{\circ} \mathrm{C} / \mathrm{min}$, temperature of the third plateau $5^{\circ} \mathrm{C}$ and duration of third plateau $5 \mathrm{~min}$ as described by Simona et al. (2013).

\section{Pan bread preparation}

The straight dough method for pan bread making was carried out according to the method described by AACC (2002b) with different ratio of ingredients as follows: The ingredients consisted of wheat flour $(500 \mathrm{~g})$, water according to require, dry yeast $(20 \mathrm{~g})$, salt $(20 \mathrm{~g})$, sugar $(50 \mathrm{~g})$, and corn oil $(60 \mathrm{ml})$. After fermentation dough was placed in greased baking pans and baked at $220^{\circ} \mathrm{C}$ in the baking oven for $20 \mathrm{~min}$., Baked loaves were cooled to room temperature 
and stored overnight in polyethylene bags before quality evaluation.

\section{Determination of bread volume, specific volume and density}

Bread volume was determined using the method of rapeseed displacement (AACC, 2000). The average weight ( $\mathrm{g}$ ) of pan bread was determined individually within one hour after baking by using a 2-decimal digital weighing scale. Bread specific volume $(\mathrm{ml} / \mathrm{g})$ and density $\left(\mathrm{g} / \mathrm{cm}^{3}\right)$ were calculated according to the methods of AACC (2002b) and Shogren et al. (2003), respectively using the following equations:

Specific volume $(\mathrm{ml} / \mathrm{g})=$ volume $\left(\mathrm{cm}^{3}\right) /$ weight $(\mathrm{g})$

Density $\left(\mathrm{g} / \mathrm{cm}^{3}\right)=$ loaf weight $/$ loaf volume

\section{Weight loss}

The dough and the baked loaf bread were weighed and per cent weight loss calculated as shown in the following equation below:

Weight loss $(\%)=$ Weight of dough-weight of bread loaf / Weigh of dough

\section{Colour Measurement}

Colour attribute $\left(\mathrm{L}^{*}, \mathrm{a}^{*}\right.$ and $\left.\mathrm{b}^{*}\right)$ of bread samples was performed using Hunter lab colour analyzer (Hunter lab colour Flex EZ, USA) according to Roa et al. (2011). The colour intensity (C), hue angle (hab) and total colour difference $\Delta \mathrm{E}$ were calculated in comparison to untreated (control) sample: where hab $0^{\circ} \mathrm{C}$ for red hue and hab $=90^{\circ} \mathrm{C}$ for yellow hue. The results were calculated using the following equations:

$$
\begin{aligned}
& \mathrm{C}^{*}=\left(\mathrm{a}^{* 2}+\mathrm{b}^{* 2}\right)^{0.5} \\
& \text { hab }=\tan -1\left(\mathrm{~b}^{*} / \mathrm{a}^{*}\right) \\
& \mathrm{WI}=100-\left[\left(100-\mathrm{L}^{*}\right)^{2}+\mathrm{a}^{* 2}+\mathrm{b}^{* 2}\right] 0.5 \\
& \Delta \mathrm{E}=\left[(\mathrm{L}-\mathrm{L} 0)^{2}+(\mathrm{a}-\mathrm{a} 0)^{2}+(\mathrm{b}-\mathrm{b} 0)^{2}\right]^{0.5}
\end{aligned}
$$

Where Lo, $\mathrm{a} 0$ and $\mathrm{b} 0$ were the $\mathrm{L}, \mathrm{a}$, and $\mathrm{b}$ values of the control sample

\section{Chemical analyses and calories value of pan bread}

Moisture, crude fat, total fiber, ash and crude protein contents were determined according to the methods described in AOAC (2008). Total carbohydrate was calculated by difference.

Total caloric content was determined according to Lawrence (1965) by using the following equation:

Total caloric $(\mathrm{Kcal} / 100 \mathrm{~g})=($ protein content $\times$ $4)+($ fat content $\times 9)+($ carbohydrate content $\times 4)$.

Determination of total phenolic compounds was determined according to Singleton et al. (1999) and Dewanto et al. (2002).

\section{Sensory Evaluation}

The staff members of the Food Science Department, Zagazig University, were asked to evaluate the prepared pan bread samples. Panelists were asked to rate each sensory attribute of the pan bread (Aroma, taste, crust colour, crumb colour, crumb texture and over all acceptability) using 9-point hedonic scale according to the following scoring system; 1 extremely dislike, 5 neither like nor dislike, and 9, extremely like (Hooda and Jood, 2005).

\section{Statistical Analysis}

All the data of the present study were subjected to analysis of variance (ANOVA) using SAS Software (SAS, 1990). Difference between means were calculated by the least significant difference (LSD) at $\mathrm{p}<0.05$ All measurements were carried out in triplicate.

\section{RESULTS AND DISCUSSION}

\section{Flour Characteristics}

Mixolab device was used to describe dough behavior during mixing and heating in a single test, simulating the mixing and baking processes. The Mixolab parameters are dough consistency during mixing (C1), mixing stability, protein weakening as a function of mechanical work and temperature $(\mathrm{C} 2)$, starch gelatinization (C3), amylase activity and hot gel stability (C4) and starch retrogradation in the cooling phase (C5). Mixolab characteristics of wheat flour and wheat flour containing different levels of full fat flaxseed flour (FFF) and defatted flaxseed flour (DFF) are presented in Table 1. Water absorption and dough stability were decreased with addition of wheat flour by FFF and DFF. C1 and C2 values were slightly 
Table 1. Mixolab measurement properties of flour fortification with full fat flaxseed flour and defatted flaxseed flour

\begin{tabular}{lcccccccc}
\hline Mixolab parameter & $\begin{array}{c}\text { Flour } \\
\text { moisture } \\
(\%)\end{array}$ & $\begin{array}{c}\text { Water } \\
\text { absorption } \\
(\%)\end{array}$ & $\begin{array}{c}\text { Dough } \\
\text { stability } \\
\text { (min) }\end{array}$ & $\begin{array}{c}\text { C1 } \\
(\mathbf{N m})\end{array}$ & $\begin{array}{c}\text { C2 } \\
(\mathbf{N m})\end{array}$ & $\begin{array}{c}\text { C3 } \\
\text { (Nm) }\end{array}$ & $\begin{array}{c}\text { C4 } \\
(\mathbf{N m})\end{array}$ & $\begin{array}{c}\text { C5 } \\
(\mathbf{N m})\end{array}$ \\
\hline Control (Flour 72\%) & 13.26 & 59.00 & 10.18 & 1.06 & 0.531 & 1.907 & 1.796 & 3.295 \\
Bread with FFF 5\% & 12.96 & 55.90 & 10.33 & 1.056 & 0.515 & 1.724 & 1.747 & 3.201 \\
Bread with FFF 10\% & 12.60 & 52.90 & 10.00 & 1.079 & 0.489 & 1.568 & 1.618 & 3.005 \\
Bread with FFF 15\% & 12.25 & 52.00 & 9.08 & 1.144 & 0.47 & 1.48 & 1.497 & 2.817 \\
Bread with DFF 5\% & 13.14 & 56.90 & 10.08 & 1.128 & 0.541 & 1.768 & 1.765 & 3.194 \\
Bread with DFF 10\% & 12.91 & 57.80 & 9.50 & 1.119 & 0.525 & 1.704 & 1.584 & 2.889 \\
Bread with DFF 15\% & 12.59 & 58.00 & 9.38 & 1.089 & 0.505 & 1.667 & 1.519 & 2.637 \\
\hline
\end{tabular}

affected by fortification flour with FFF and DFF. Mixolab C1 and C2 values are related to gluten quality; higher values indicate weaker gluten properties (Koksel et al., 2009). It was found that $\mathrm{C} 1$ values in bread samples fortified with FFF and DFF were higher than that in the control sample. $\mathrm{C} 3$ and $\mathrm{C} 4$ values were decreased by addition of FFF and DFF. Decreased viscosity peak (C3) with less starch components addition. These results are in line with those found by Hadnadev (2011) who found lower viscosity peak with lower starch content.

\section{Physical Characteristics of Pan Bread}

Physical characteristics (volume, weight and specific volume) of pan bread were affected by FFF and DFF addition (Table 2). In general, loaf volume and specific volume were decreased in all samples compared to the control $\left(2725 \mathrm{~cm}^{3}\right.$ and 3.13 , respectively) except for specific volume of $5 \% \mathrm{FFF}$, it was increased. Similar effect was observed with bread density while, the decrease in specific volume may be due to the lower gluten content in the flaxseed bread. Lower specific volume values of bread with the addition or partial replacement of wheat flour with non-glutinous flour may be due to the lower gluten in the additives which gives less active gluten network and gas trapping and that might be strongly related to higher bread hardness reported in a previous section of bread texture (Dervas et al., 1999; Doxastakis et al., 2002).

\section{Bread Colour}

Colour analysis of processed food is an important field, always related strongly to market and consumers acceptability as it controls the first impression of any food product (Yoo et al., 2006). Table 3 shows colour values of crumb and crust of control and flaxseed bread samples. It was found that the control bread was lighter in colour than bread of FFFor DFF, where L value was the highest in both crust and crumb samples (51.36 and 73.05, respectively). These results are in coincidence and confirmed with that obtained by Sariconban and Imaz, ( 2010); Abou-Zaid et al., (2012). Regarding the crumb colour, increasing the percentage of FFF and DFF to wheat flours decreased $L^{*}, b^{*}$ and WI values and increased $a^{*}$ values compared with the control. Subjective evaluation confirmed that the FFF and DFF bread samples were darker, more red (a-values) than control samples. These results are in agreement with those obtained by Ahamed (1999) and Kenny et al. (2000).

\section{Chemical Composition of Full Fat and Defatted Flaxseed Flour}

Proximate composition: protein, crude fiber, crude fat, ash, carbohydrate and moisture of full flaxseed and defatted flaxseed flour are shown in Table 4. It is clear that the defatted flaxseed flour had higher moisture, crude protein, ash, and crude fiber contents $(6.77,28.636 .95$ and $8.8 \%$, respectively) compared to full fat flaxseed flour. It means that the utilization of full fat flaxseed flour and defatted flaxseed flour in some bakery products increase their content of fiber. 
Table 2. Effect of addition full flaxseed flour and defatted flaxseed flour on physical properties of pan bread

\begin{tabular}{lcccccc}
\hline & $\begin{array}{c}\text { Parameter Loaf weight Loaf weight } \\
\text { before }\end{array}$ & $\begin{array}{c}\text { Weight } \\
\text { loss }(\mathbf{g})\end{array}$ & $\begin{array}{c}\text { Loaf } \\
\text { volume }\left(\mathbf{g} / \mathbf{c m}^{3}\right)\end{array}$ & $\begin{array}{c}\text { Density } \\
\left(\mathbf{g} / \mathbf{c m}^{3}\right)\end{array}$ & $\begin{array}{c}\text { Specific } \\
\text { volume } \\
\left(\mathbf{c m}^{3} / \mathbf{g}\right)\end{array}$ \\
\hline Control & $904.04^{\mathrm{g}}$ & $871.71^{\mathrm{f}}$ & $32.33 \mathrm{~g}$ & $2725^{\mathrm{a}}$ & $0.32^{\mathrm{d}}$ & $3.13^{\mathrm{b}}$ \\
Bread with 5\% FFF & $936.68^{\mathrm{f}}$ & $841.61^{\mathrm{g}}$ & $95.07^{\mathrm{a}}$ & $2685^{\mathrm{c}}$ & $0.31^{\mathrm{d}}$ & $3.19^{\mathrm{a}}$ \\
Bread with 10\% FFF & $943.53^{\mathrm{d}}$ & $890.59^{\mathrm{e}}$ & $52.94^{\mathrm{b}}$ & $2380^{\mathrm{d}}$ & $0.37^{\mathrm{c}}$ & $2.67^{\mathrm{d}}$ \\
Bread with 15\% FFF & $977.16^{\mathrm{b}}$ & $925.40^{\mathrm{b}}$ & $51.71^{\mathrm{c}}$ & $2230^{\mathrm{g}}$ & $0.41^{\mathrm{b}}$ & $2.41^{\mathrm{f}}$ \\
Bread with 5\% DFF & $940.44^{\mathrm{e}}$ & $890.96^{\mathrm{d}}$ & $49.48^{\mathrm{f}}$ & $2695^{\mathrm{b}}$ & $0.33^{\mathrm{d}}$ & $3.02^{\mathrm{c}}$ \\
Bread with 10\% DFF & $962.39^{\mathrm{c}}$ & $912.18^{\mathrm{c}}$ & $50.21^{\mathrm{e}}$ & $2285^{\mathrm{e}}$ & $0.40^{\mathrm{b}}$ & $2.50^{\mathrm{e}}$ \\
Bread with 15\% DFF & $1008.77^{\mathrm{a}}$ & $958.13^{\mathrm{a}}$ & $50.66^{\mathrm{d}}$ & $2245^{\mathrm{f}}$ & $0.43^{\mathrm{a}}$ & $2.34^{\mathrm{g}}$ \\
\hline
\end{tabular}

The same letters in the column means insignificant differences.

Table 3. Effect of fortification FFF or DFF on colour characteristics of pan bread crust and crumb samples

\begin{tabular}{|c|c|c|c|c|c|c|c|}
\hline Sample & $\mathbf{L}^{*}$ & $a^{*}$ & $\mathbf{b}^{*}$ & $\mathrm{C}^{*}$ & $\mathbf{h}_{\mathrm{ab}}$ & WI & $\begin{array}{c}\text { Differences } \\
\Delta E\end{array}$ \\
\hline & \multicolumn{7}{|c|}{ Crust samples } \\
\hline Control & $51.36^{\mathrm{a}}$ & $10.94^{\mathrm{c}}$ & $22.33^{\mathrm{a}}$ & $24.87^{\mathrm{a}}$ & $88.74^{\mathrm{a}}$ & $45.37^{\mathrm{a}}$ & $0.00^{\mathrm{g}}$ \\
\hline Bread with FFF 5\% & $34.11^{\mathrm{e}}$ & $11.83^{\mathrm{a}}$ & $15.03^{\mathrm{d}}$ & $19.13^{\mathrm{c}}$ & $88.18^{\mathrm{f}}$ & $31.39^{\mathrm{f}}$ & $18.75^{\mathrm{c}}$ \\
\hline Bread with FFF $10 \%$ & $32.62^{\mathrm{g}}$ & $10.93^{\mathrm{d}}$ & $13.64^{\mathrm{g}}$ & $17.48^{\mathrm{f}}$ & $88.12^{\mathrm{g}}$ & $30.39^{\mathrm{g}}$ & $20.66^{\mathrm{a}}$ \\
\hline Bread with FFF 15\% & $34.02^{f}$ & $10.32^{\mathrm{e}}$ & $13.91^{\mathrm{f}}$ & $17.32^{\mathrm{g}}$ & $88.20^{\mathrm{e}}$ & $31.78^{\mathrm{e}}$ & $19.29^{\mathrm{b}}$ \\
\hline Bread with DFF 5\% & $36.91^{b}$ & $10.97^{\mathrm{b}}$ & $16.08^{\mathrm{b}}$ & $19.47^{b}$ & $88.31^{\mathrm{b}}$ & $33.98^{\mathrm{b}}$ & $15.74^{\mathrm{f}}$ \\
\hline Bread with DFF $10 \%$ & $35.77^{\mathrm{d}}$ & $10.23^{\mathrm{g}}$ & $15.68^{\mathrm{c}}$ & $18.72^{\mathrm{d}}$ & $88.27^{\mathrm{d}}$ & $33.10^{\mathrm{d}}$ & $16.96^{\mathrm{e}}$ \\
\hline \multirow[t]{2}{*}{ Bread with DFF $15 \%$} & $35.82^{\mathrm{c}}$ & $10.25^{\mathrm{f}}$ & $14.81^{\mathrm{e}}$ & $18.01^{\mathrm{e}}$ & $88.28^{\mathrm{c}}$ & $33.34^{\mathrm{c}}$ & $17.28^{\mathrm{d}}$ \\
\hline & \multicolumn{7}{|c|}{ Crumb simples } \\
\hline Control & $73.05^{\mathrm{a}}$ & $0.89^{\mathrm{f}}$ & $17.02^{\mathrm{a}}$ & $17.04^{\mathrm{a}}$ & $89.16^{\mathrm{a}}$ & $68.11^{\mathrm{a}}$ & $0.00^{\mathrm{g}}$ \\
\hline Bread with FFF $5 \%$ & $64.37^{\mathrm{b}}$ & $0.38^{\mathrm{g}}$ & $15.45^{\mathrm{b}}$ & $15.45^{\mathrm{b}}$ & $89.06^{\mathrm{c}}$ & $61.16^{\mathrm{c}}$ & $8.84^{\mathrm{f}}$ \\
\hline Bread with FFF $10 \%$ & $55.7^{\mathrm{f}}$ & $1.58^{\mathrm{d}}$ & $15.22^{\mathrm{c}}$ & $15.30^{\mathrm{c}}$ & $88.92^{\mathrm{e}}$ & $53.13^{\mathrm{f}}$ & $17.46^{\mathrm{b}}$ \\
\hline Bread with FFF 15\% & $57.12^{\mathrm{d}}$ & $2.13^{\mathrm{b}}$ & $13.26^{\mathrm{e}}$ & $13.43^{\mathrm{e}}$ & $88.96^{\mathrm{d}}$ & $55.07^{\mathrm{d}}$ & $16.41^{\mathrm{d}}$ \\
\hline Bread with DFF 5\% & $63.97^{\mathrm{c}}$ & $1.12^{\mathrm{e}}$ & $4.74^{\mathrm{g}}$ & $4.87^{\mathrm{g}}$ & $89.10^{\mathrm{b}}$ & $63.64^{\mathrm{b}}$ & $15.27^{\mathrm{e}}$ \\
\hline Bread with DFF $10 \%$ & $56.84^{\mathrm{e}}$ & $1.97^{\mathrm{c}}$ & $14.46^{\mathrm{d}}$ & $14.59^{\mathrm{d}}$ & $88.95^{\mathrm{d}}$ & $54.44^{\mathrm{e}}$ & $16.45^{\mathrm{c}}$ \\
\hline Bread with DFF $15 \%$ & $54.66^{\mathrm{g}}$ & $3.08^{\mathrm{a}}$ & $12.91^{\mathrm{f}}$ & $13.27^{\mathrm{f}}$ & $88.91^{\mathrm{e}}$ & $52.76^{\mathrm{g}}$ & $18.97^{\mathrm{a}}$ \\
\hline
\end{tabular}

The same letters in the column means insignificant deferences. 
Table 4. Chemical composition of full flaxseed flour and defatted flaxseed flour

\begin{tabular}{lcccccc}
\hline Analaysis & Moisture & Protein & Fat & Ash & Total fiber & Carbohydrate \\
\hline FFF & $3.96^{\mathrm{b}}$ & $26.23^{\mathrm{b}}$ & $48.38^{\mathrm{a}}$ & $5.82^{\mathrm{b}}$ & $8.5^{\mathrm{b}}$ & $5.55^{\mathrm{b}}$ \\
FDF & $6.77^{\mathrm{a}}$ & $28.63^{\mathrm{a}}$ & $0.24^{\mathrm{b}}$ & $6.95^{\mathrm{a}}$ & $8.8^{\mathrm{a}}$ & $8.58^{\mathrm{a}}$ \\
\hline
\end{tabular}

Chemical composition of ban bread fortificated with full fad flaxseed or defatted flaxseed flour

It could be also noticed that the utilization of FFF and DFF in pan bread decreased gradually, its content of carbohydrates and caloric value as the level of addition was increased (Table 5). The highest caloric value and carbohydrate content were found in control bread (304.62 and $49.30 \%$, respectively) while, the lowest were found in bread fortified with 15\% DFF (269.15 and $34.75 \%$, respectively). Protein content was ranged between 12.05 in control bread to $14.47 \%$ in bread of $15 \%$ FFF. The increase in protein, ash and fiber contents in pan bread samples were due to their higher contents in FFF and DFF than in flour. The decrease in carbohydrates and caloric value in pan bread samples were due to the highest fiber contents in FFF and DFF. These results are in agreement with those obtained by Hussain et al. (2012) who had reported significant improvement in the proximate composition (ash, crude protein, fat and crude fiber) of full fat flaxseed flour supplemented whole wheat flour.

\section{Sensory Evaluation}

Sensory evaluation is considered to be one of the limiting factors for consumer acceptability. The results of sensory evaluation of control and flaxseed bread samples are shown in Table 6. It was noticed that bread sample fortified with $5 \%$
FFF had the highest sensory scores in taste, crust colour, aroma and overall acceptability being $8.67,8.45,8.62$ and 8.66, respectively. Therefore, addition of FFF and DFF enhanced most of sensory attributes of pan bread and were acceptable until level of $10 \%$. Similar results were found by Pourabedin et al. (2017) who reported that crust colour was evaluated as the best for the bread with $10 \%$ flaxseed and no significant differences were found for the crumb colour of $10 \%, 20 \%$, and control samples. Also, Kaur et al. (2013) stated that flaxseed can be used to improve the nutritive value of bakery products as well as for improving sensory properties.

\section{Conclusion}

This study demonstrated the effect of full fat and defatted flaxseed flour on the physicchemical and sensorial quality of pan bread. From the obtained results it can be concluded that water absorption and dough stability were decreased while the protein and dietary fiber contents of the bread samples were increased with fortification wheat flour with FFF and DFF. As the flaxseed addition level increased the caloric values of the obtained bread were decreased. Bread sample fortified with 5\% FFF had the best sensory scores in taste, crust colour, aroma and overall acceptability. Fortification of pan bread with flaxseed flour can be accepted up to $10 \%$ without change in its sensory quality. 
Zagazig J. Agric. Res., Vol. 45 No. (1) 2018

Table 5. Proximate analysis and caloric value of pan bread containing substituted flour with different levels of full flaxseed flour or defatted flaxseed flour

\begin{tabular}{|c|c|c|c|c|c|c|c|}
\hline Chemical composition & $\begin{array}{l}\text { Moistur } \\
\text { e }(\%)\end{array}$ & $\begin{array}{l}\text { Ash } \\
(\%)\end{array}$ & $\begin{array}{l}\text { Fat } \\
(\%)\end{array}$ & $\begin{array}{l}\text { Protein } \\
\quad(\%)\end{array}$ & $\begin{array}{l}\text { Fiber }( \\
(\%)\end{array}$ & $\begin{array}{l}\text { arbohydrate } \\
\qquad(\%)\end{array}$ & $\begin{array}{r}\text { e Caloric value } \\
\text { (K.cal./100g) }\end{array}$ \\
\hline control & $34.64^{f}$ & $3.64^{g}$ & $6.58^{\mathrm{g}}$ & $12.05^{\mathrm{g}}$ & $0.37^{\mathrm{g}}$ & $49.30^{\mathrm{a}}$ & $304.62^{\mathrm{a}}$ \\
\hline Bread with full flaxseed flour (5\%) & $36.16^{\mathrm{d}}$ & $4.19^{\mathrm{e}}$ & $10.16^{\mathrm{c}}$ & $12.19^{\mathrm{f}}$ & $0.58^{\mathrm{f}}$ & $36.72^{\mathrm{c}}$ & $287.08^{d}$ \\
\hline Bread with full flaxseed flour $(10 \%)$ & $35.50^{\mathrm{e}}$ & $4.28^{d}$ & $10.68^{b}$ & $12.40^{\mathrm{e}}$ & $0.91^{\mathrm{e}}$ & $36.05^{\mathrm{d}}$ & $289.92^{c}$ \\
\hline Bread with full flaxseed flour (15\%) & $33.67^{\mathrm{g}}$ & $5.54^{\mathrm{a}}$ & $11.19^{\mathrm{a}}$ & $13.45^{\mathrm{c}}$ & $1.26^{\mathrm{c}}$ & $34.89^{\mathrm{f}}$ & $294.07^{b}$ \\
\hline Bread with defatted flaxseed flour $(5 \%)$ & $36.74^{\mathrm{a}}$ & $3.81^{\mathrm{f}}$ & $8.37^{\mathrm{d}}$ & $12.58^{\mathrm{d}}$ & $0.98^{d}$ & $37.52^{b}$ & $275.73^{\mathrm{e}}$ \\
\hline Bread with defatted flaxseed flour $(10 \%)$ & $36.56^{\mathrm{b}}$ & $4.57^{\mathrm{c}}$ & $8.37^{\mathrm{dd}}$ & $13.76^{\mathrm{b}}$ & $1.31^{\mathrm{b}}$ & $35.43^{\mathrm{e}}$ & $272.09^{f}$ \\
\hline Bread with defatted flaxseed flour $(15 \%)$ & $36.53^{c}$ & $4.84^{\mathrm{b}}$ & $8.03^{f}$ & $14.47^{\mathrm{a}}$ & $1.38^{\mathrm{a}}$ & $34.75^{\mathrm{g}}$ & $269.15^{\mathrm{g}}$ \\
\hline LSD & 0.0175 & 0.0175 & 0.0175 & 0.0175 & 1.2850 & 0.0166 & 0.0175 \\
\hline
\end{tabular}

Total carbohydrateis obtained by difference. Total carbohydrate $=100-(\%$ moisture $+\%$ ash $+\%$ protein $+\%$ fat + $\%$ crude fibre)

Table 6. Sensory evaluation of pan bread fortified with full fat flaxseed flour or defatted flaxseed flour

\begin{tabular}{|c|c|c|c|c|c|c|}
\hline Sensory parametar & Taste & $\begin{array}{l}\text { Crust } \\
\text { colour } \\
(9)\end{array}$ & $\begin{array}{c}\text { Crumb } \\
\text { colour } \\
(9)\end{array}$ & $\begin{array}{c}\text { Aroma } \\
\text { (9) }\end{array}$ & $\begin{array}{c}\text { Texture } \\
\text { (9) }\end{array}$ & $\begin{array}{c}\text { Overall } \\
\text { acceptability } \\
\text { (9) }\end{array}$ \\
\hline Control & $8.57^{\mathrm{a}}$ & $8.33^{\text {cd }}$ & $8.63^{\mathrm{a}}$ & $8.55^{\mathrm{b}}$ & $8.23^{\mathrm{a}}$ & $8.65^{\mathrm{a}}$ \\
\hline Bread with full flaxseed flour $5 \%$ & $8.67^{\mathrm{a}}$ & $8.45^{\mathrm{b}}$ & $8.56^{\mathrm{a}}$ & $8.62^{\mathrm{a}}$ & $8.17^{\mathrm{a}}$ & $8.66^{\mathrm{a}}$ \\
\hline Bread with full flaxseed flour $10 \%$ & $7.33 \mathrm{c}$ & $8.20^{\mathrm{e}}$ & $7.33^{\mathrm{c}}$ & $7.49^{\mathrm{f}}$ & $7.43^{\mathrm{c}}$ & $7.83^{\mathrm{c}}$ \\
\hline Bread with full flaxseed flour $15 \%$ & $6.17^{\mathrm{e}}$ & $8.15^{\mathrm{e}}$ & $6.57^{\mathrm{e}}$ & $7.17^{\mathrm{g}}$ & $6.01^{\mathrm{e}}$ & $6.90^{\mathrm{e}}$ \\
\hline Bread with defatted flaxseed flour $5 \%$ & $8.13^{\mathrm{b}}$ & $8.37^{\mathrm{bc}}$ & $8.47^{\mathrm{b}}$ & $8.33^{\mathrm{c}}$ & $8.07^{\mathrm{b}}$ & $8.67^{\mathrm{a}}$ \\
\hline Bread with defatted flaxseed flour $10 \%$ & $7.79^{\mathrm{ab}}$ & $8.25^{\mathrm{de}}$ & $7.33^{\mathrm{c}}$ & $7.97^{\mathrm{d}}$ & $7.43^{\mathrm{c}}$ & $7.93^{\mathrm{b}}$ \\
\hline Bread with defatted flaxseed flour $15 \%$ & $6.67^{\mathrm{d}}$ & $8.10^{\mathrm{a}}$ & $6.67^{\mathrm{d}}$ & $7.75^{\mathrm{e}}$ & $6.33^{\mathrm{d}}$ & $7.67^{\mathrm{d}}$ \\
\hline LSD & 0.332 & 0.087 & 0.087 & 0.091 & 0.087 & 0.087 \\
\hline
\end{tabular}

\section{REFERENCE}

AACC (2000). Approved methods of American association of cereal chemists $\left(10^{\text {th }} \mathrm{Ed}\right.$.). St Paul: Ame. Ass. of Cereal Chem., Inc.

AACC (2002a). Approved Method of American Association of Cereal Chemists Published by American Association of Cereal Chemists Published Paul. Minn. St. USA.
AACC (2002b). Approved Methods of American Association Of Cereal Chemists, Methods 10-50D, 44-15 and 4612.AACC. Int., St. poul, MN.

Abou-Zaid, A.A.M., M.A.S. El-Bandy and H. Ismaeil (2012). Rheological properties and quality evaluation of pan bread and biscuits supplemented with mushroom micelles flours. Aust. J. Basic and Appl. Sci., 6 (6): 237- 245. 
Agu, H.O., J.A. Ukonze and K.A. Paul (2010). Quality characteristics of bread, made from wheat and fluted pumpkin seed flour. Nig. Food. J., 28 : 188- 198.

Ahamed, Z.S. (1999). Effect of hydrocolloids in Egyptian balady bread on baking quality, J. Agric. Sci., Mansoura Univ., 24 : 3535-3544.

AOAC (2008). Official Methods of Analysis $16^{\text {th }}$ Ed. Ass. of Official Anal. Chem. Int. Arligton, Virginia, USA.

Badifu, S.O., C.E. Chima, Y.I. Aayi and A.F. Ogori (2005). Influence of mango mesocare flour supplement to micronutrient, Physical and organoleptic qualities of wheat- basedbread. Nig. Food J., 23 : 59- 68.

Bonet, B. and C.M. Rosell (2006). Formation of homopolymeters and heteropolymeters between 1 wheat flour and several protein sources by 2 trans glutaminase catalyzed cross linking. Cereal Chem., 83(6): 655-662.

Dervas, G., G. Doxastakis, S. HadjisavvaZinoviadi and N. Triantafillakos (1999). Lupine flour addition to wheat flour doughs and effect on rheological properties. Food Chem., 66: 67-73.

Dewanto, V., X. Wu, K.K. Adom and R.H. Liu (2002). Thermal processing enhances the nutritional value of tomatoes by increasing total antioxidant activity. J. Agric. Food Chem., 50 (10): 3010-3014.

Doxastakis, G., I. Zafiriadis, M. Irakli, H. Marlani and C. Tananaki (2002). Lupin, soya and triticale addition to wheat flour doughs and their effects on rheological properties. Food Chem., 77: 219-227.

El-Demery, M., F.M. Khaled, F.B. Gamil and A. Waleed (2015). Effect of fortification by full fat and defatted flaxseed flour of sensory properties of wheat bread and lipid profile laste. Int. J. Curr. Microbiol. App. Sci., 4 (4): 581-598.

Gimai, S.Y., D.B. Mepha, K. Kabari and S.D. Achienewhn (2003). Evaluation of the nutritional quality of breads prepared from wheat- fluted pumpki n (Telferia occidentis Hooks) seed flour blends. Plant Food Health. Nutr., $58: 1-8$.
Hadnadev, T.D., A. Torbica and M. Hadnadev (2011). Rheological properties of wheat flour substitutes/alternative crops assessed by Mixolab. Proc. Food Sci., 1: 328-334.

Hooda, S. and Jood (2005). Organoleptic and nutritional evaluation of wheat biscuits supplemented with untreated and treated fenugreek flour. Food Chem., 90 (3) : 427-435.

Hussain, S., F.M. Anjum, M.S. Butt, M.S. Alamri and M.R. Khan (2012). Biochemical and nutritional evaluation of unleavened flat breads fortified with healthy flaxseed. Int. J. Agric Biol., 14:190 - 196.

Johnsson, P., A. Kamal-Eldin, L.N. Lundgren and P. Aman (2000). HPLC method for analysis of secoisolariciresinol diglucoside in flaxseeds. J. Agric. Food Chem., 48: 5216219.

Kajla, P., A. Sharma and D.R. Sood (2014). Flaxseed-A potential functional food source. Food source. J. Food Sci. Technol., 52 (4): 1857-1871.

Kasote, D.M. (2013). Flaxseed phenolics as natural antioxidants. Int. Food Res. J., 20 (1): 27-34.

Kaur, A., V. Sandhu and K. S. Sandhu (2013). Effects of flaxseed addition on sensory and baking quality of whole wheat bread. Int. J. Food Nutr. and Safety, 4 (1): 43-54.

Kenny, S., W. Karina, S. Catherine and A. Elke (2000). Incorporation of dairy ingredients into wheat bread : Effects on dough rheology and bread quality. Eur. Food Res. Technol., $210: 391-396$.

Koksel, H., K. Kahraman, T. Sanal, D.S. Ozay, and A. Dubat (2009). Potential utilization of mixolab for quality evaluation of bread wheat genotypes. Cereal Chem., 86 (5): $522-$ 526.

Lawrence, R.D. (1965).The diabetic life. J. and A. Churchill, LTD. London.

Mercier, S., S. Villeneuve, C. Moresoli, M. Mondor, B. Marcos and K.A. Power (2014). Flaxseed-enriched cereal-based products: A review of the impact of processing 
conditions. Comp. Rev. Food Sci. and Food Safety, 13(4): 400-412.

Pourabedin M., A. Aarabi and S. Rahbaran (2017). Effect of flaxseed flour on rheological properties, staling and total phenol of Iranian toast. J. Cereal Sci., 76: 173-178.

Roa, L.H., L.Y. Khizar, E. Karangwa, S.Q. Xia, C.S. Jia and X.M. Zhang (2011). Effect of ultrafilration adsorbents on the clarification of green tea. J. Food Eng., 102 : 321-326.

Sariconban, C. and M.T.Y. Imaz (2010). Modeling the effect of processing factors on the changes in colour parameters of cooked meat ball using response surface methodology. World Appl. Sci. J., 9(1):14-22.

SAS (1990). Institute Inc. SAS/STAT User's Guide volume 2, Version 6, $4^{\text {th }}$ Ed., Cary, $\mathrm{NC}: \mathrm{SAS}$ Inst. Inc.

Seczyk, L., M. Swieca, D. Dziki, A .Anders and U. Gawlik-Dziki (2017). Antioxidant, nutritional and functional characteristics of wheat bread enriched with ground flaxseed hulls. Food Chem., 214: 32-38.

Selomulyo, V.O. and W. Zhou (2007). Frozen bread dough: effects of freezing storage and dough improvers. J. Cereal Sci., 45:1-17.

Shahidi, F. (2002). Nutraceuticals and functional foods: research addresses bioactive components. Food Technol., 56: 13-24.
Shogren, R.L., A.A. Mohamed and C.J. Cariere (2003). Sensory analysis of whole wheat/soy flour breads. Sensory and Nut. Quality of Food, 68:2141-2145.

Siddiq, M., M. Nasir, R. Ravi, M.S. Butt, K.D. Dolan and J.B. Harte (2009). Effect of defatted maize germ flour addition on the physical and sensory quality of wheat bread. LWT- Food Sci. and Technol., 42: 464-470.

Simona, A., A. Ersilia, N. Monica, G. Emilia and A. Lazureanu (2013). Studies regarding rheological properties of tritical, wheat and rye flours, J. Hort., Forestry and Biotechnol., 17 (1): 345-349.

Singleton, V., R. Orthofer and R. LamuelaRaventos (1999). Analysis of total phenols and other oxidation substrates and antioxidants by means of Folin-Ciocalteau reagent. Oxidants and antioxidants part A. Methods in Enzymol., 299: 152-178.

Thompson, L.U. (1995). Flaxseed in Human Nutrition, Cunnane, SC, Thompson, LU. (eds.). AOCS Press, Champaign, 219-236 and 261-280.

Yoo, J.S., E.J. Seog and J.H. Lee (2006). Bread quality as influenced by sweet pumpkin powder. J. Food Sci. and Nut., 11: 339-343.

\section{تأثير إضافة دقيق بذور الكتان الكامل ومنزوع الزيت على جودة خبـز القالب

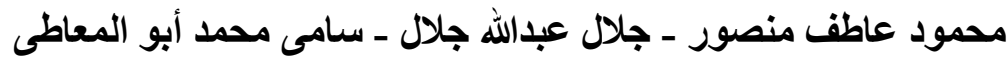

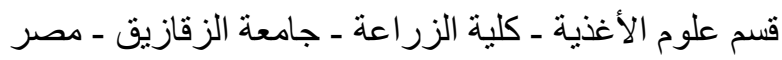

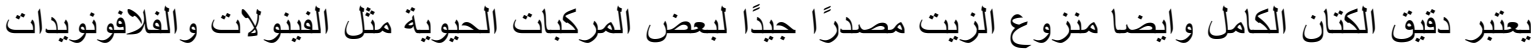

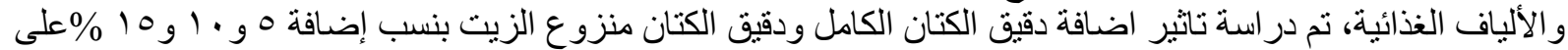

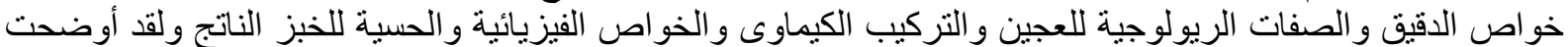

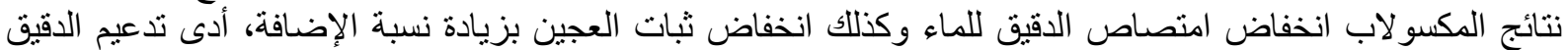

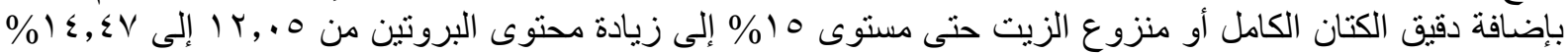

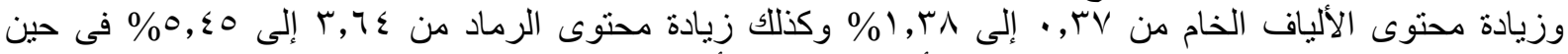

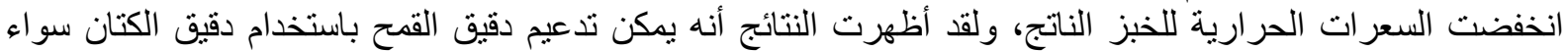

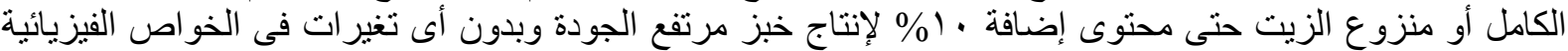

